\title{
Study of surgical site infection in patients undergoing caesarean section at tertiary care center, Gujarat
}

\author{
Vishal Prajapati, Komal P. Modi* \\ Department of Obstetrics and Gynecology, GMERS Medical College and Civil Hospital, Himmatnagar, Gujarat, India
}

Received: 07 January 2022

Accepted: 01 February 2022

\author{
*Correspondence: \\ Dr. Komal P. Modi, \\ E-mail: drkomalgujarati@gmail.com
}

Copyright: ( $)$ the author(s), publisher and licensee Medip Academy. This is an open-access article distributed under the terms of the Creative Commons Attribution Non-Commercial License, which permits unrestricted non-commercial use, distribution, and reproduction in any medium, provided the original work is properly cited.

\begin{abstract}
Background: Surgical site infection following cesarean delivery leads to increasing the duration of patient hospitalization, hospital costs and raise the burden on our healthcare system. The incidence of SSI after cesarean range from $3 \%$ to $5 \%$. Objective of current investigation was to study the risk factor \& microbial agents responsible for SSI in LSCS and impact of SSI on perinatal outcome.

Methods: This prospective study was done among 324 pregnant women undergoing LSCS at department of obstetrics and Gynecology in GMERS medical college \& hospital, Sola, Ahmedabad during April 2015 to April 2016. All patients were following up to $7^{\text {th }}$ postoperative day.SSI was defined by CDC criteria.

Results: The incidence of SSI noted in present study was $8.02 \%$. Almost $46.2 \%$ cases had BMI $\geq 25 \mathrm{~kg} / \mathrm{m}^{2}, 65.4 \%$ multipara, $34.6 \%$ resided in rural area of SSI group. PIH, PROM, LSCS in emergency, multiple vaginal examination $(>3)$, perioperative blood glucose $(\geq 110 \mathrm{mg} / \mathrm{dl})$, duration of surgery $(\geq 60 \mathrm{~min})$, past $\mathrm{H} / \mathrm{O}$ of LSCS noted in participants of SSI was 30.8\%, 30.8\%, 96.1, 19.3\%, 84.6\%, 23.1\%), 73.1\% respectively. Staphylococcus aureus was the most common microorganism identified and incidence of NICU admission was 11.5\% in SSI group.

Conclusions: Incidence of SSI in present is $8.02 \%$. BMI, PIH, PROM, LSCS in emergency, multiple vaginal examination ( $>3$ ), perioperative blood glucose $(\geq 110 \mathrm{mg} / \mathrm{dl})$, duration of surgery ( $\geq 60 \mathrm{~min})$, Past H/O of LSCS were noted statistically significantly higher among the participants of SSI group. Staphylococcus aureus was the most common organism identified.
\end{abstract}

Keywords: Cesarean delivery, Incidence of SSI, Microorganism, Risk factor, Surgical site infection

\section{INTRODUCTION}

A caesarean section (CS) is an operation in which surgery was made through a mother's abdominal wall and underlying tissues to dislodge the baby. ${ }^{1}$ Out of all major abdominal operation, CS is the most common procedure done among women in both developed and developing nations. ${ }^{2}$ Adverse event like infection, postpartum hemorrhage, bladder injury and increased risks during future pregnancies also noted after $\mathrm{CS}^{3}{ }^{3}$ Surgical site infection (SSI) following caesarean delivery leads to increasing the duration of patient hospitalization, hospital costs and raise the burden on our healthcare system. ${ }^{4}$ The incidence of SSI after caesarean ranges from $3 \%$ to $5 \% .^{5}$ The incidence rate of SSI following CS associated with many factors like wound class, maternal age, hypertensive disorders, types of CS procedures, number of vaginal examinations, high volume of blood loss during surgery, diabetes, maternal weight, surgical techniques and premature rupture ofmembrane. ${ }^{6-11}$ Incidence of episodes of fever, endometritis, wound infection; urinary tract infection and serious infection after caesarean section can be reduce by use of prophylactic antibiotics in women undergoing caesarean section. ${ }^{12}$ So, present study was conducted with the objectives to study the risk factor and microbial agents 
responsible for SSI in LSCS and impact of SSI on perinatal outcome.

\section{METHODS}

This prospective study was done among 324 pregnant women undergoing LSCS at department of obstetrics \& gynecology in GMERS medical college \& hospital, Sola, Ahmedabad during April 2015 to April 2016. Data collection was done after ethical permission from institutional ethical committee and informed consent of clients. Pre-tested questionnaire was administered and details like socio-demographic information, past history of medical illness, menstrual history, obstetrical history, history of previous operation, medical illness was collected. Postoperatively women were monitored for signs of infection. Surgical wound was inspected at the time of first sign of SSI and daily thereafter, till the discharge of patient. All patients were following up to $7^{\text {th }}$ postoperative day. Those who do not develop SSI suture removal was done on $7^{\text {th }}$ post-operative day. SSI was defined by CDC criteria. Information about the SSI would include the date of SSI, specific criteria met for identifying the SSI, when/how the SSI is detected, whether the patient develops a secondary bloodstream infection, and the organisms isolated from cultures and the organisms' antimicrobial susceptibilities. Out of 324 pregnant women, 26 patients had developed wound site infection as per CDC criteria and 298 had not. The data were recorded in an Excel sheet and descriptive analysis was performed, of which data are presented in the tables. To know the association between dependent and independent variables chi-square was applied accordingly, $\mathrm{p}$ value less than 0.05 was considered as statistically significant.

\section{RESULTS}

Total $3.8 \%$ participants of group SSI and $3.4 \%$ of group 'without SSI' were $\geq 35$ years age respectively $(p>0.05)$ and mean age was 27.3 years and 25.6 years of the participants of SSI and 'without SSI' group respectively ( $>0.05$ ) (Table 1). Almost 34.6\% participants of group SSI and 7\% of group 'without SSI' came from rural area respectively $(\mathrm{p}<0.05)$. Almost $69.5 \%$ participants of group SSI and $67.1 \%$ of group 'without SSI' belonged to lower socio-economic class respectively $(\mathrm{p}<0.05)$. Almost $46.2 \%$ participants of group SSI and $23.8 \%$ of group 'without SSI' noted with BMI $\geq 25$ $\mathrm{kg} / \mathrm{m}^{2}$ respectively $(\mathrm{p}<0.05)$. Almost $65.4 \%$ participants of group SSI and $63.1 \%$ of group 'without SSI' noted with multiparity respectively $(\mathrm{p}<0.05)$. Almost $53.8 \%$ participants of group SSI and $42 \%$ of group 'without SSI' noted with GA $\leq 37$ weeks respectively $(p>0.05)$.

Risk factor like PIH, PROM, LSCS in emergency, multiple vaginal examination (>3), postoperative hemoglobin $(<11 \mathrm{gm} / \mathrm{dl})$, perioperative blood glucose $(\geq 110 \mathrm{mg} / \mathrm{dl})$, fat thickness $(<2 \mathrm{~cm})$, duration of surgery ( $\geq 60 \mathrm{~min}$ ), past $\mathrm{H} / \mathrm{O}$ of LSCS noted in participants of SSI
\& 'without SSI' group was $30.8 \%$ vs. $8.7 \%(\mathrm{p}<0.05)$, $30.8 \%$ vs. $8 \% \quad(\mathrm{p}<0.05), 96.1 \%$ vs. $74.5 \% \quad(\mathrm{p}<0.05)$, $19.3 \%$ vs. $6.1 \% \quad(p<0.05), 92.3 \%$ vs. $83.8 \% \quad(p>0.05)$, $84.6 \%$ vs. $47 \% \quad(\mathrm{p}<0.05), 30.8 \%$ vs. $19.8 \% \quad(\mathrm{p}>0.05)$, $23.1 \%$ vs. $7 \% \quad(\mathrm{p}<0.05), 73.1 \%$ vs. $52 \% \quad(\mathrm{p}<0.05)$ respectively (Table 2 ).

Table 1: Distribution of socio-clinico characteristics of study participants $(n=324)$.

\begin{tabular}{|c|c|c|c|}
\hline \multirow[b]{2}{*}{ Parameters } & \multicolumn{2}{|l|}{ Groups } & \multirow[b]{2}{*}{$\begin{array}{l}\mathbf{P} \\
\text { value }\end{array}$} \\
\hline & $\begin{array}{l}\text { SSI }(\mathrm{N}=26) \\
\text { Frequency } \\
(\%)\end{array}$ & $\begin{array}{l}\text { Without SSI } \\
(\mathrm{N}=298) \\
\text { Frequency }(\%)\end{array}$ & \\
\hline \multicolumn{4}{|l|}{ Age (year) } \\
\hline$<35$ & $25(96.2)$ & $288(96.6)$ & \multirow{2}{*}{0.89} \\
\hline$\geq 35$ & $1(3.8)$ & $10(3.4)$ & \\
\hline Mean age & 27.3 & 25.6 & 0.12 \\
\hline \multicolumn{4}{|l|}{ Residence } \\
\hline Rural & $9(34.6)$ & $21(7)$ & \multirow{2}{*}{0.001} \\
\hline Urban & $17(65.4)$ & $277(93)$ & \\
\hline \multicolumn{4}{|c|}{ Socioeconomic class } \\
\hline Higher & $0(0.0)$ & $3(1.0)$ & \multirow{3}{*}{0.87} \\
\hline Middle & $8(30.5)$ & $95(31.9)$ & \\
\hline Lower & $18(69.5)$ & $200(67.1)$ & \\
\hline \multicolumn{4}{|l|}{ BMI $\left(\mathrm{kg} / \mathrm{m}^{2}\right)$} \\
\hline$<25$ & $14(53.8)$ & $227(76.2)$ & \multirow{2}{*}{0.01} \\
\hline$\geq 25$ & $12(46.2)$ & $71(23.8)$ & \\
\hline \multicolumn{4}{|l|}{ Parity } \\
\hline Primi & $9(34.6)$ & $110(36.9)$ & \multirow{2}{*}{0.05} \\
\hline Multi & $17(65.4)$ & $188(63.1)$ & \\
\hline \multicolumn{4}{|c|}{ Gestational age (weeks) } \\
\hline$\leq 37$ & $14(53.8)$ & $125(42.0)$ & \multirow{2}{*}{0.23} \\
\hline$>37$ & $12(46.2)$ & $173(58.0)$ & \\
\hline
\end{tabular}

Microorganism like Staphylococcus aureus, Klebsiella, Acinetobacter, E. coli, Pseudomonas, showed no growth isolated from the surgical site of SSI among the $26.9 \%$, $15.5 \%, 7.7 \%, 3.8 \%, 3.8 \%, 42.3 \%$ participants of SSI group respectively (Figure 1). NICU admission required in $11.5 \%$ participants of SSI group and $12 \%$ of 'without SSI' group ( $\mathrm{p}>0.05)$ as depicted in (Figure 2).

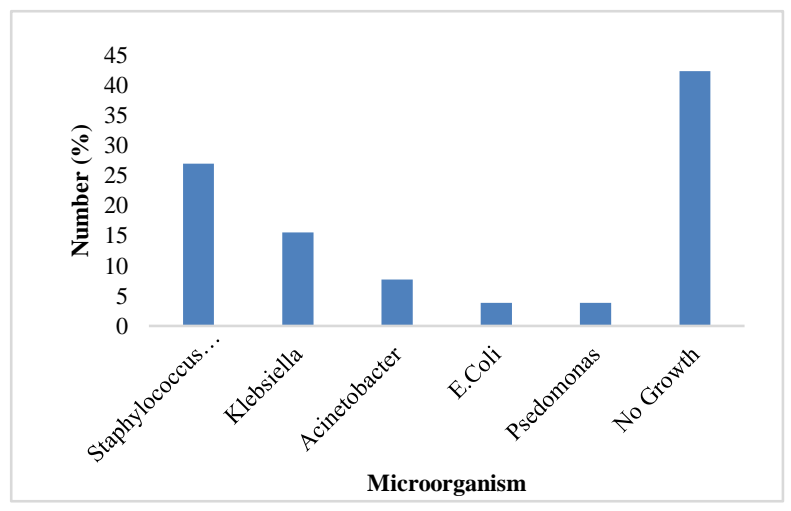

Figure 1: Microorganism isolated from surgical site among the participants of SSI group $(n=26)$. 
Table 2: Distribution of risk factor for SSI in LSCS among study participants ( $=324)$.

\begin{tabular}{|c|c|c|c|}
\hline \multirow[b]{2}{*}{ Parameters } & \multicolumn{2}{|l|}{ Groups } & \multirow[b]{2}{*}{ P value } \\
\hline & $\begin{array}{l}\text { SSI }(N=26) \\
\text { frequency }(\%)\end{array}$ & $\begin{array}{l}\text { Without SSI }(\mathrm{N}=298) \\
\text { frequency }(\%)\end{array}$ & \\
\hline PIH & $8(30.8)$ & $26(8.7)$ & 0.001 \\
\hline PROM & $8(30.8)$ & $24(8.0)$ & 0.0001 \\
\hline LSCS in emergency & $25(96.1)$ & $222(74.5)$ & 0.02 \\
\hline Multiple vaginal examination $(>3)$ & $5(19.3)$ & $18(6.1)$ & 0.01 \\
\hline Postoperative hemoglobin (<11 gm/dl) & $24(92.3)$ & $250(83.8)$ & 0.42 \\
\hline Perioperative blood glucose ( $\geq 110 \mathrm{mg} / \mathrm{dl})$, mean (mg/dl) & $22(84.6), 118$ & $140(47.0), 101$ & $0.001,0.02$ \\
\hline Fat thickness $(<2 \mathrm{~cm})$ & $8(30.8)$ & $59(19.8)$ & 0.18 \\
\hline Duration of surgery ( $\geq 60$ min) & $6(23.1)$ & $21(7.0)$ & 0.004 \\
\hline Past H/O of LSCS & $19(73.1)$ & $155(52.0)$ & 0.03 \\
\hline
\end{tabular}

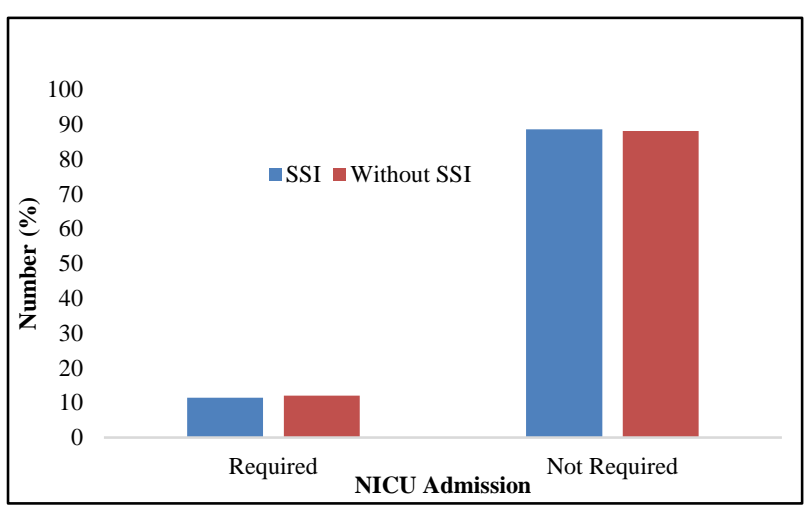

Figure 2: NICU admission required among the participants $(n=324)$.

\section{DISCUSSION}

The study was conducted for analysis of surgical site infection in caesarean section of 324 patients, so the incidence of SSI noted in present study was $8.02 \%$. Present study noted statistically not significantly almost similar age distribution among participants of both the groups. Present study registered statistically significantly 5 times higher number of rural participants in SSI group compare to 'without SSI' group. Present study noted statistically not significantly almost similar S-E status distribution among participants of both the groups.

Present study observed that BMI $\geq 25 \mathrm{~kg} / \mathrm{m}^{2}$ noted statistically significantly among almost double number of participants of SSI group compare to 'without SSI' group. This finding is correlate with the study done by De D et al. ${ }^{16}$ Present study noted statistically significantly almost similar parity distribution among participants of both the groups. In present study, wound infections were more in multiparous women. Out of 26 patients 17 are multiparous women. Similar result was found in Bhadauria et al and Rehman et al in their studies, they observed that SSI was more in case of multiparous women. They said malnutrition and anemia due to repeated child birth could be the predisposing factors for SSI occurrence in multiparous women. ${ }^{17-19}$

Table 3: Comparison of 'incidence of SSI' of present study with other similar study.

\begin{tabular}{|ll|}
\hline Study & Incidence of SSI (\%) \\
\hline Wloch et $\mathbf{~ a l ~}^{\mathbf{1 3}}$ & 9.6 \\
\hline Gupta et $\mathbf{~ a l}^{\mathbf{1 4}}$ & 10.3 \\
\hline Gelaw et $\mathbf{~ a l}^{\mathbf{1 5}}$ & 6.8 \\
\hline De et al $^{\mathbf{1 6}}$ & 24.2 \\
\hline Filbert et $\mathbf{~ a l}^{\mathbf{1 7}}$ & 10.9 \\
\hline Al Jama et al & 4.2 \\
\hline Present study & 8.02 \\
\hline
\end{tabular}

Present study found that risk factor like PIH, PROM, LSCS in emergency, multiple vaginal examination $(>3)$, perioperative blood glucose $(\geq 110 \mathrm{mg} / \mathrm{dl})$, duration of surgery $(\geq 60 \mathrm{~min})$, past $\mathrm{H} / \mathrm{O}$ of LSCS were noted statistically significantly higher among the participants of SSI group compare to 'without SSI' group. Risk factor like postoperative hemoglobin $(<11 \mathrm{gm} / \mathrm{dl})$ and fat thickness $(<2 \mathrm{~cm})$ also noted higher among the participants of SSI group compare to 'without SSI' group but it was statistically not significant. These finding is correlate with the study done by Dessu et al, Amenu et al, Bizimana et al, Chu et al, Karl et al, Callaghan et al. ${ }^{20-25}$ Present study also sent all the sample from each case of SSI group for microorganism identification and it was found Staphylococcus aureus was the most common organism identified. This finding is correlate with the study done by De et al, Al Jama et al and Dhar et al. ${ }^{16,5,26}$ Study done by Mhaske et al found MRSA (37.5\%)was the commonest pathogen to produce SSI in our series, followed by sterile culture in $21 \%$ cases. ${ }^{27}$ Bhavani et al found that most common pathogens were $S$. aureus, Pseudomonas aeruginosa and E. coli, as was also observed in their study. ${ }^{28}$ Present study observed that incidence of NICU admission was almost similar among both the groups but it was statistically not significant. 


\section{CONCLUSION}

The present study highlights on the incidence of wound infection, possible risk factors for SSI and etiology of wound infection. Incidence of SSI in present is $8.02 \%$.It was evident from the present study that random blood glucose level $\geq 110 \mathrm{mg} / \mathrm{dl}$ has more chance of SSI. It was concluded that BMI $\geq 25 \mathrm{~kg} / \mathrm{m} 2$ is associated with development of SSI. It was concluded that patients from rural area, presence of PIH, presence of PROM, multiple vaginal examination is associated with development of SSI. It was evident from present study that patients having emergency LSCS and duration of surgery $\geq 60$ minutes have had more chance of SSI. Patients having emergency LSCS and having any risk factor mention above have had increased chances of SSI. We isolated Staphylococcus aureus as a most common microorganism causing wound infection. Staphylococcus aureus is $71.4 \%$ sensitive to prophylactic antibiotics. In present study perinatal outcome was not affected in patients with SSI.

Funding: No funding sources

Conflict of interest: None declared

Ethical approval: The study was approved by the Institutional Ethics Committee

\section{REFERENCES}

1. Kelemu A, Amlaku M, Feleke H, Birhanu W, Liknaw B. Surgical site infection and its associated factors following cesarean section. BMC. 2017; 11(17):2-8.

2. Betra'́n A, Merialdi M, Lauer J, Bing-Shun W, Thomas J, Look PV, et al. Rates of caesarean section: analysis of global, regional and national estimates. Paediatr Perinat Epidemiol. 2007;21(2): 98-113.

3. American College of Obstetricians and Gynecologists, Society for Maternal-Fetal Medicine. Obstetric care consensus no. 1: safe prevention of the primary cesarean delivery. Obstet Gynecol. 2014; 123(3):693-711.

4. Blumenfeld YJ, El-Sayed YY, Lyell DJ. Risk factors for prolonged postpartum length of stay following cesarean delivery. Am J Perinatol. 2015;32(9):82532.

5. Al Jama FE. Risk factors for wound infection after lower segment cesarean section. Qatar Med J. 2012; 2012(2):26-31.

6. Vijayan C, Mohandas S, Nath AG. Surgical site infection following cesarean section in a teaching hospital. Int J Sci Stud. 2016;3(12):97-101.

7. Olsen MA, Butler AM, Willers DM, Devkota P, Gross GA, Fraser VJ. Risk factors for surgical site infection after low transverse cesarean section. Infect Control Hosp Epidemiol. 2008;29(6):477-84.

8. Jalil MHA, Hammour KA, Alsous M, Awad W, Hadadden R, Bakri F, et al. Surgical site infections following caesarean operations at a Jordanian teaching hospital: frequency and implicated factors. Sci Rep. 2017;7(1):12210.

9. Gong SP, Guo HX, Zhou HZ, Chen L, Yu YH. Morbidity and risk factors for surgical site infection following cesarean section in Guangdong Province, China. J Obstet Gynaecol Res. 2012;38(3):509-15.

10. Shrestha S, Shrestha R, Shrestha B, Dongol A. Incidence and risk factors of surgical site infection following cesarean section at Dhulikhel hospital. Kathmandu Univ Med J. 2014;46(2):113-6.

11. Mpogoro FJ, Mshana SE, Mirambo MM, Kidenya BR, Gumodoka B, Imirzalioglu C. Incidence and predictors of surgical site infections following caesarean sections at Bugando medical Centre, Mwanza, Tanzania. Antimicrob Resist Infect Control. 2014;3(1):25.

12. Smaill F, Hofmeyr GJ. Antibiotic prophylaxis for cesarean section. Cochrane Database Syst Rev. 2002; 5:CD933.

13. Wloch C, Wilson J. Risk factors for surgical site infection following caesarean section in England: results from a multicentre cohort study. BJOG. 2012; 119(11):1324-33.

14. Gupta S, Manchanda V, Sachdev P, Saini RK, Joy $M$. Study of incidence and risk factors of surgical site infections in lower segment caesarean section cases of tertiary care hospital of north India. Indian J Med Microbiol. 2021;39(1):1-5.

15. Gelaw K, Aweke AM. Surgical site infection and its associated factors following cesarean section: a cross sectional study from a public hospital in Ethiopia. Patient Safety Surg. 2017;11:18.

16. De D, Saxena S, Mehta G, Yadav R, Dutta R. Risk Factor Analysis and Microbial Etiology of Surgical Site infection following lower segment cesarean section. Int J Antibiotics. 2013;2013:283025.

17. Filbert J, Stephen E, Mariam M , Benson R , Balthazar $\mathrm{G}$, Imirzalioglu $\mathrm{C}$ et al. Incidence and predictors of surgical site infections following caesarean sections at Bugando Medical Centre, Mwanza, Tanzania. Antimicrob Resi Infect Control. 2014;3(25):1-10.

18. Bhadauria AR. Clinical study of post operative wound infections in obstetrics and gynaecological surgeries in a tertiary care set up. Int $\mathrm{J}$ Reprod Contracept Obstet Gynecol. 2013;2(4):631-8.

19. Rahman J. Factors of Post-operative wound infection in abdominal surgeries of Obstetrics and Gynaecology department. J Dhaka Nat Med College Hospital. 2012;18(1):39-42.

20. Dessu S, Samuel S, Gebremeskel F, Basazin A, Tariku Z, Markos M. Determinants of post cesarean section surgical site infection at public hospitals in Dire Dawa administration, Eastern Ethiopia: Case control study. PLoS ONE. 2021;16(4):e0250174.

21. Amenu D, Belachew T, Araya F. Surgical site infection rate and risk factors among obstetric cases of Jimma University Specialized Hospital, southwest Ethiopia. Ethiop J Health Sci. 2011;21:91-200. 
22. Bizimana J, Ndoli J, Bayingana C, Baluhe I, Gilson G. Prevalence and risk factors for post cesarean delivery surgical site infection in a teaching hospital setting in rural Rwanda: A prospective cross sectional study. Int J Curr Microbiol App Sci. 2016; 5:631-41.

23. Chu K, Maine R, Trelles M. Cesarean section surgical site infections in sub-saharan africa: a multi country study from medecins sans frontieres. World J Surj. 2014:1-7.

24. Karl W. Reducing the complications of caesarean section. Adv Obstetr Gynaecol 2017;20:141-52.

25. Callaghan W, Creanga A, Kuklina E. Severe maternal morbidity among delivery and postpartum hospitalizations in the United States. Obstet Gynecol. 2012;120:1029-36.
26. Dhar H. A study of post-caesarean section wound infections in a regional referral hospital. Oman. Sultan Qaboos Univ Med J. 2014;14(2):e211.

27. Mhaske G, Vadhera P, Kalra K. Study of surgical site infection (SSI) in patients undergoing caesarean section (CS): A retrospective study. Int J Clin Obstet Gynaecol. 2020;4(1):350-3.

28. Bhavani K, Prasanthi S, Jyothsna Y, Vani I, Uma N. A critical review of post-operative caesarean section sepsis: A retrospective study. IAIM. 2017;4(11):1539.

Cite this article as: Prajapati V, Modi PK. Study of surgical site infection in patients undergoing caesarean section at tertiary care center, Gujarat. Int J Reprod Contracept Obstet Gynecol 2022;11:844-8. 